\title{
ОСНОВНІ ВЛАДНІ СУБ' СКТИ ДОСУДОВОГО РОЗСЛІДУВАННЯ І ЇХНІ КРИМІНАЛЬНІ ПРОЦЕСУАЛЬНІ ФУНКЦІї
}

\author{
АДАМОВ Федор Павлович - аспірант арківського науково-дослідного \\ інституту судових експертиз імені Заслуженого професора М. С. Бокаріуса \\ Міністерства юстиції України
}

УДК 343 (477)

https://orcid.org/0000-0003-1844-1835

DOI $10.32782 / E P .2020 .3 .19$

\begin{abstract}
У статті визначаються основні владні суб'єкти, які діють у стадї досудового розслідування, їхні кримінальні процесуальні функиій та висвітлюються проблеми, що вимагають подальшого законодавчого удосконалення фбнкціональної діяльності кожного із ичих суб’єктів. Автор акцентує увагу на тому, шо закріплена

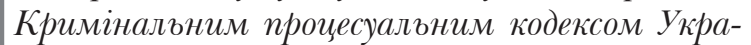
їни 2012 року нова борма вітчизняного кримінального процесу, побудованого на підставі конституційних приницпів змагальності та рівності сторін кримінального провадження, обумовила необхідність запровадження до стадї досудового розслідування судового контролю з метою недопущення будь-яких порушень конституиійних прав учасників кримінальної прочесуальной діяльності з боку владних суб'єктів досудового розслідування зі сторони обвинувачення: прокурора та слідчого при виконанні ними прочесуальних дій, прийнятті процесуальних рішень та застосуванні примусових заходів процесуального характеру (заходів забезпечення кримінального провадження). Дослідник надходить до висновку, щзо процесуальна діяльність владних суб’єктів досудового розслідування, як і всіх учасників кримінального провадження, є тісно пов'язаною.

Ключові слова: кримінальне провадження, досудове розслідування, дізнавач, слідиии, прокурор, слідчий суддя, кримінальна прочесуальна бункиія, законодавещь.
\end{abstract}

\section{Постановка проблеми}

Виконання судово-контрольної функції у досудовому розслідуванні законодавець по- клав на нового владного суб'єкта цієї стадії провадження - слідчого суддю (п. 18 ч. 1 ст. 3 КПК України). Діяльність означеного владного суб'єкта має важливе значення, оскільки від його процесуальних залежать: хід і результати досудового розслідування; забезпечення недоторканності прав, свобод і законних інтересів учасників процесу; успішне виконання завдань кримінального провадження, визначених ст. 2 КПК України. Тож у стадії досудового розслідування, найбільш тісно пов'язаній із застосуванням заходів процесуального примусу та більш ніж істотним обмеженням прав і свобод учасників кримінального провадження, судово-контрольна діяльність слідчого судді є надійною конституційною гарантією забезпечення прав, свобод і законних інтересів громадян, втягнутих у сферу кримінальної процесуальної діяльності.

За своєю правовою природою процесуальна діяльність слідчого судді у досудовому розслідуванні є контрольною функцією органів судової влади. Ця функція реалізується слідчим суддею під час судового засідання, де вирішується спір між сторонами обвинувачення і захисту у змагальному порядку. За результатами проведених змагань слідчий суддя приймає процесуальні рішення (ухвали) про: застосування заходів забезпечення кримінального провадження; надання дозволу на прдоведення слідчих (розшукових) дій; негласних слідчих (розшукових) дій, інших процесуальних дій; розгляд скарг учасників кримінального провадження на рішення, дії чи бездіяльність слідчого, прокурора. Це означає, що процесу- 


\section{Кримінальне право, кримінальний процес та криміналістика}

альна діяльність владних суб'єктів досудового розслідування, як і всіх учасників кримінального провадження, є тісно пов'язаною $з$ діяльністю слідчого судді. Проте глибокі наукові дослідження з питань взаємодії учасників сторони обвинувачення зі слідчим суддею до цих пір не проводилися, що не сприяє підвищенню результативності кримінальної процесуальної діяльності. Для подолання цього вважається за необхідне здійснити, з урахуванням вимог до об'єму цієї наукової публікації, комплексний аналіз основних владних суб'єктів досудового розслідування та дослідити їхні кримінальні процесуальні функції.

Аналіз останніх досліджень і публікацій

Після введення в дію КПК України 2012 року ряд вітчизняних учених-правознавців, серед яких М. А. Макаров, М. А. Погорецький, В. Ю. Шепітько, А. Д. У далова, О. Г. Яновська, В. О. Попелюшко, В. Я. Марчак, Н. С. Карпов, C. В. Сськов та інші, провів чимало наукових досліджень з питань процесуального статусу судді, його процесуальних рішень, правових основ та ролі і місця у досудовому розслідуванні. Так, М. А. Макаров уже захистив докторську дисертацію з проблем теоретичних та правових основ контролю у кримінальному процеci. У той же час проблема взаємодії учасників обвинувачення, які дають у стадії досудового розслідування продовжує залишатися майже не дослідженою.

Метою статті $є$ удосконалення реалізації принципу верховенства права на стадії досудового розслідування.

\section{Результати дослідження}

Пунктом 10 частини 1 статті 3 Кримінального процесуального кодексу України 2012 року (далі - КПК України) визначено дві обов'язкові форми (фази) кримінального провадження - досудову і судову, на які вказують самі їх назви закріплені в законі. Ці форми (фази) кримінальної процесуальної діяльності є відносно самостійними як за своїм характером, направленістю, так і за результатами, не дивлячись на те, що перша з них в основному функціонує до суду і для суду [1, с. 119]. У першій формі (фазі) кримінального провадження здійснюється розкриття і розслідування кримі- нальних правопорушень - кримінальних проступків і злочинів шляхом збирання, фіксації, перевірки, оцінки і накопичення доказів, тобто проведення неймовірно складного матеріально-пошукового дослідження обставин вчиненого кримінально-карного діяння, визначеного Кримінальним кодексом України. Визначальне місце серед досудових стадій належить стадії, що йменується досудовим розслідуванням кримінальних правопорушень (п. 5 ч. 1 ст. 3 КПК України), бо саме тут формується основний обсяг доказової інформації по кримінальній справі, необхідний для законного, обгрунтованого і справедливого iї вирішення судом першої інстанції. Тож не випадково досудову форму (фазу) матеріального дослідження, що проводиться в досудових стадіях кримінального провадження і йменується доказуваннямпізнанням, вчені-правознавці визначають фундаментом процесуальної діяльності, а судовий розгляд кримінальної справи, що проводиться в судових стадіях і йменується доказуваннямобгрунтуванням, вони визначають покрівлею процесуальної діяльності [2, с. 59].

Виходячи $з$ того, що саме у стадії досудового розслідування кримінальних правопорушень закладаються основи кримінального провадження i, що за своїм характером i змістом досудове розслідування $є$ найтяжчим, найоб'ємнішим і найскладнішим видом кримінальної процесуальної діяльності, вітчизняний законодавець обгрунтовано сформував тут найчисельнішу групу владних суб'єктів, які представляють різні гілки державної влади і покликані забезпечити кримінальну справу до їі судового розгляду повними і неспростовними доказами [3, с. 41; 4, с. 19]. Більше того, законодавець пов'язав цих владних суб'єктів такими кримінальними процесуальними правовідносинами, за яких процесуальна діяльність одного владного суб'єкта досудового розслідування входить до процесуальної діяльності іншого владного суб'єкта в якості iї обов'язкового структурного елемента, у результаті чого вся їхня процесуальна діяльність є взаємопов' язаною, взаємозалежною, взаємообумовленою і без цієї причинно-діалектичної єдності просто не існує [5, с. 21].

Основними владними суб'єктами досудового розслідування є дізнавач і слідчий, бо тільки вони наділені правом розслідувати криміналь- 
ні правопорушення у повному обсязі. Сама назва означеної стадії кримінального провадження як «стадії досудового розслідування» (п. 5 ч. 1 ст. 3 КПК України) є яскравим свідченням того, що вона присвячена виключно розслідуванню кримінальних правопорушень (кримінальних проступків і злочинів), що основними владними суб'єктами тут виступають дізнавач і слідчий, а їхньою визначальною кримінальною процесуальною функцією 6 тільки проведення всебічного, повного і неупередженого матеріально-пошукового дослідження (розслідування) всіх обставин вчиненого кримінального правопорушення [6, с. 120-136]. Крім цієі ведучої для них кримінальної процесуальної функції (ст. 40, 40 КПК України), законодавець зобов’язав дізнавача і слідчого виконувати в межах наданих їм повноважень ще й обвинувальну та загальнодержавну правозабезпечуючу (правозахисну) функції.

Звичайно, функція обвинувачення є конституційною (ст.131-1 Основного Закону) і неподільною. Її виконання в обох формах (досудовій і судовій), визначених пунктами 3 та 13 частини 1 статті 3 КПК України, реалізується тільки прокурором. Дізнавач і слідчий виконують лише одне із положень обвинувальної функції, вимагаючи при формуванні доказів на законних підставах залучати до кримінальної справи всі докази обвинувального характеру, не ігноруючи жодного з них, бо це може унеможливити формування прокурором матеріально-правового обвинувачення в досудовій фазі кримінального провадження, та належним чином підтримати процесуальне (державне) обвинувачення в суді [7, с. 179]. Що ж до загальнодержавної правозахисної функції, визначеної ст. 3 Конституції України, то вона є обов’язковою для виконання всіма державними органами України без будь-якого винятку. У такій гострій сфері державної діяльності, як кримінальний процес, іiї повинні виконувати всі владні суб'єкти кримінального провадження, які діютьна всіх стадіях кримінального провадження.

Поділивши кримінальний процес (кримінальне провадження) на дві його форми (фази): досудове провадження і судове провадження, законодавець спеціальним параграфом КПК України (параграф 1 глави 3 «Суд i підсудність») детально розкрив функціональне призначення органів кримінального правосуддя у кримінальному процесі. У той же час в означеній главі 3 відсутній спеціальний параграф, присвячений детальному розкриттю функціонального призначення другої форми кримінального процесу під назвою «Органи досудового розслідування і їхня підслідність», що не демонструє єдності цих двох обов'язкових форм (фаз) процесу. Розкиданість процесуальних норм, регламентуючих кримінальну процесуальну діяльність органів дізнання і досудового слідства, не надає чіткого уявлення про їхнє функціональне призначення. Процесуальні статуси дізнавача і слідчого повинні бути чітко і однозначно визначені на законодавчому рівні. Крім того, не дивлячись на пряму вимогу п. 14 ст. 92 Конституції України про необхідність розроблення і прийняття Закону України «Про органи досудового розслідування», Верховна Рада України протягом 24 років ухиляється від виконання цієї вимоги і продовжує регламентувати слідчу діяльність лише процедурним законом, яким 6 КПК України, що завдає діяльності дізнавачів і слідчих суттєвого ураження, бо залишає велику частину їхньої організації і діяльності без належного законодавчого забезпечення. Без вирішення означених нами проблем на законодавчому рівні органи дізнання і досудового слідства ефективно працювати не будуть.

Другим владним суб'єктом досудового розслідування, на якого законодавець покладає обов'язок 3 виконання основоположної (загальнопроцесуальної) функції обвинувачення у першій іï досудовій формі як порушення обвинувачення проти особи, що безпосередньо вчинила кримінальне правопорушення, тобто у формі «твердження про вчинення певною особою діяння, передбаченого Законом України про кримінальну відповідальність, висунуте в порядку, встановленому КПК України» (п. 13 ч. 1 ст. 3 КПК України). Щоб забезпечити це матеріально-правове обвинувачення належними доказами, законодавець поклав на прокурора, який діяв на стадії досудового розслідування, виконання кримінальної процесуальної функції здійснення постійного прокурорського нагляду за додерженням законів дізнавачами і слідчими під час проведення ними досудового розслідування кримінальних правопорушень. Цю функцію прокурор виконує у формі проце- 


\section{Кримінальне право, кримінальний процес та криміналістика}

суального керівництва досудовим розслідуванням (ч. 2 ст. 36 КПК України). Прокурор - це посадова особа самостійного державного органу, який не відноситься до жодної з гілок влади і діє у різний спосіб на всіх стадіях кримінального провадження без винятку [8, с. 74-77]. Кримінальні процесуальні наглядові повноваження прокурора у стадії досудового розслідування чітко визначені ст. 36 КПК України.

Крім обвинувальної і наглядової функції, прокурор в означеній стадії кримінального провадження виконує ще й загальнодержавну правозабезпечувальну (правозахисну) та процесуальну координаційну функції. Перша 3 них направлена на недопущення будь-яких порушень прав учасників досудового розслідування як з боку дізнавача і слідчого, так і з боку одного учасника кримінального провадження проти іншого учасника цього провадження. Друга функція направлена на забезпечення узгоджувальних дій як між різними слідчими, які розслідують одну складну багатоепізодну справу, так і між слідчими та співробітниками оперативно-розшукових органів, які супроводжують розслідування складних кримінальних справ. Багатофункціональна діяльність прокурора, iї постійний і безперервний характер, владно-розпорядчий характер його процесуальних повноважень у стадії досудового розслідування, дозволяють йому негайно виявити будь-які порушення закону, допущені під час проведення досудового розслідування кримінальних правопорушень і своєю владою негайно їх усувати. Крім того, процесуальний статус прокурора, який діє на стадії досудового розслідування, дозволяє йому виключати саму можливість незаконного i необгрунтованого притягнення невинуватої особи до кримінальної відповідальності [9, с. 76-77]. Для підвищення результативності прокурорської обвинувальної досудової діяльності нагальною $\epsilon$ потреба доповнити кримінальне провадження України новою досудовою стадією під назвою «порушення обвинувачення», бо в межах стадії досудового розслідування цю функцію прокурору виконувати досить складно.

Третім владним суб'єктом досудового розслідування є слідчий суддя, на якого законодавець покладає виконання судово-контрольної функції, спрямованої на недопущення незаконих обмежень конституційних прав і свобод осіб (учасників процесу), залучених чи допущених до кримінального провадження, з боку державних органів, які ведуть кримінальний процес, використовуючи широкий арсенал примусових заходів процесуального характеру i уособлюючи собою саму державу. До таких владних суб'єктів законодавець відносить: дізнавача, слідчого, прокурора. Суть судового контролю виражається в тому, що жоден примусовий захід процесуального характеру не може бути застосований дізнавачем, слідчим i прокурором без проведення слідчим суддею попередньої глибокої перевірки на предмет його законності з послідуючою дачею згоди чи відмови в дачі згоди на його застосування. Тож судовий контроль є найвищою конституційною гарантією, що убезпечує права і свободи учасників досудового розслідування від будь-яких їх незаконних порушень з боку державних органів, які ведуть кримінальний процес. I хоч усі свої судово-контрольні рішення (ухвали) слідчий суддя приймає не за власною ініціативою, а лише за письмовими клопотаннями дізнавача, слідчого, прокурора чи за письмовими скаргами учасників досудового розслідування на визначені ст. 303 КПК України рішення, дії або бездіяльність цих владних суб'єктів кримінального провадження, його вагомий внесок у недоторканість конституційних прав людини і громадянина та підвищення якості досудового розслідування кримінальних правопорушень є очевидним [10, с. 7-8]. Судовий контроль - новий інститут вітчизняного кримінального провадження, тому він ще не набув повної досконалості. Законодавець навіть не врегулював саму процедуру - процесуальний порядок проведення слідчим суддею судово-контрольних проваджень (судових засідань), наділив слідчого суддю збитковими повноваженнями, залишив багато інших проблем судового контролю не врегульованими на законодавчому рівні. Усі ці проблеми чекають свого вирішення з боку Верховної Ради України.

До обов'язкових владних суб'єктів досудового розслідування чинний КПК України відносить ще й керівників органів досудового слідства (ст. 39 КПК України), керівників органів дізнання (ст. 3911 КПК України) та співробітників оперативних підрозділів (ст. 41 КПК України). Проте ці владні суб'єкти не є 
основними владними суб'єктами, які діють на стадії досудового розслідування, оскільки означені керівники не займаються кримінальною процесуальною діяльністю, не застосовують жодного примусового заходу процесуального характеру, а виконують лише відомчу організаційно-управлінську функцію по відношенню до підпорядкованих їм дізнавачів і слідчих. Співробітники ж оперативних підрозділів виконують лише разові кримінальні процесуальні дії за письмовими дорученнями дізнавачів, слідчих чи прокурорів. Жоден із цих владних суб'єктів не вступає у кримінальні процесуальні правовідносини з учасниками процесуальної діяльності, у зв'язку з чим на них навіть не розповсюджуються правила інституту відводу їх від участі у кримінальній процесуальній діяльності. Виходячи з цього, ми й обмежилися лише висвітленням функціонального призначення основних владних суб'єктів досудового розслідування та проблем, які потребують вирішення.

\section{Висновок}

Вирішення проблеми аналізу кримінальних процесуальних функцій основних владних суб'єктів досудового розслідування з їх відокремленням сприятиме не лише підвищенню ефективності діяльності сторони обвинувачення у досудовому розслідуванні, а ще й забезпечить чітке виконання принципу верховенства права у стадії досудового розслідування, відповідно до якого людина, іiі права, свободи та законні інтереси визначаються найвищими соціальними цінностями в Україні.

\section{Аiтература}

1. Рахунов Р.Д. Участники уголовно-процессуальной деятельности. Москва: Госюриздат, 1961. 277 с.

2. Трусов А.И. Уголовный процесс в системе разделения властей. Вестник МГУ: Серия «Право». 1994. № 5. С. 54-60.

3. Савонюк Р.Ю. Доказування у досудовому розслідуванні: навч. посібник. Сімферополь: Доля, 2003. 184 с.

4. Колеснік Г.Р. Функціональне призначення нагляду і контролю у досудовому розслідуванні: дис. ... канд. юрид. наук: 12.00.09. Харків, 2018. 224 с.

\section{SUMMARY}

The article identifies the main authorities operating in the pre-trial investigation, their criminal procedural functions and highlights the problems that require further legislative improvement of the functional activities of each of these entities. The author emphasizes that the new form of domestic criminal proceedings enshrined in the Criminal Procedure Code of Ukraine in 2012, based on the constitutional principles of adversarial proceedings and equality of arms, necessitated the introduction of pre-trial investigation of judicial control to prevent any violations of constitutional rights. participants in criminal proceedings by the authorities of the pretrial investigation by the prosecution: the prosecutor and the investigator in the performance of their procedural actions, the adoption of procedural decisions and the application of coercive measures of a procedural nature (measures to ensure criminal proceedings). The researcher concludes that the procedural activities of the authorities of the pre-trial investigation, as well as all participants in the criminal proceedings, are closely linked.

Key words: criminal proceedings, pre-trial investigation, coroner, investigator, prosecutor, investigating judge, criminal procedural function, legislator.

5. Півненко В.П. Кримінальна юстиція України: проблеми організації і діяльності. Право України. 2001. № 7. С. 19-22.

6. Андрусяк В.Б. Кримінальні процесуальні функції слідчого: дис. ... канд. юрид. наук: 12.00.09. Харків, 2010. 226 с.

7. Юрчишин В.М. Прокурор - суб'єкт кримінального переслідування. Правова політика держави: матер. наук.-практ. конф. (м. ІваноФранківськ, 19-20 лютого 2010 р). Т. 2. ІваноФранківськ, 2010. С. 176-180.

8. Юрчишин В.М. Нагляд прокурора за додержанням законності при провадженні досудового розслідування за новим КПК України. Вістник прокуратури. 2012. № 6. С. 74-77.

9. Кожевников О.А. Участие прокурора в досудебных стадиях уголовного судопроизводства: монография. Москва: Волтерс Клувер, 2011. 208 c.

10. Колоколов Н.А. Судебный контроль в стадии предварительного расследования: автореф. дис. ... канд. юрид. наук: 12.00.09. Москва, 1988. 23 с. 